\title{
Technological characteristics of glauconite rocks in Bakchar deposit (Western Siberia)
}

\author{
M.A. Rudmin ${ }^{1, \text { a }}$, A.K. Mazurov', B.I. Makarov ${ }^{2}$, I.V. Reva ${ }^{1}$ \\ ${ }^{1}$ National Research Tomsk Polytechnic University, Institute of Natural Resources, Department \\ of Geology and Mineral Exploration, 634050 Tomsk, Russia \\ ${ }^{2}$ Tomsk State University, Biological Institute, Department of Plant Physiology and \\ Biotechnology, 634050 Tomsk, Russia
}

\begin{abstract}
Glauconite-containing rocks found within the boundaries of the Bakchar deposit include the following: glauconite ores (glauconitolite), glauconite sandstone, hydrogoethite-chlorite, iron ores with glauconite. Glauconite content in glauconite ores is $50 \ldots 70 \%$, in glauconite sandstone $-20 \ldots 40 \%$, in hydrogoethite-chlorite ores- $10 \ldots 20 \%$. This paper describes the technological characteristics of glauconite rocks. The authors proposed the optimal technological scheme of producing glauconite concentrate. It has been defined that the most highly-qualified product with commercial components $90 \ldots 100 \%$ is recovered from glauconite ores. It has been evaluated that Bakchar glauconite is applicable as a favorable mineral fertilizer based on the concentrate produced from enriched hydrogoethite-chlorite ores. Experimentally, it has been proved that this concentrate has a positive effect on the growth of oats (Avéna satíva). This is a direct indicator of its practical applicability. Obtained results indicate the fact that the extraction and application of Bakchar glauconite could be widely used in agriculture.
\end{abstract}

\section{Introduction}

The present research is focused on the development of the technological production scheme of glauconite concentrate from enclosing rocks and its possible application in agriculture to enhance the investment potential of Bakchar deposit. Bakchar iron ore deposit in S-E area of Western Siberia (fig.1) and $200 \mathrm{~km}$. north-westward of Tomsk. This deposit is related to Western-Siberian iron ore basin which is a wide correlative belt from Turukhan river in the north to the Tobol river head in the south-west. The following large iron ore areas are within this basin (fig.1): Elogy-Turukhansky, Kargasokin, Narym- Parabelsky, Kolpashevo and well-developed Bakchar deposit.

Iron ore deposits are located within Cretaceous-Paleogene sediments at the depth of $150 \ldots 250$ meters (fig.2).Ore-hosting sediments are typical sandstones of the coastal-marine genesis: sandstones, sands, aleurolites, aleurites, clays with horizontal oolitic iron ores [1-3]. Currently, this deposit is not being developed due to unfavorable mining conditions, i.e. increased water content in overlying loose horizon. The detailed investigation of ore-hosting series indicated the fact that besides the iron in Upper Cretaceous Galkin suite there is enriched glauconite deposits (fig.2).

Glauconite group includes stratified low-temperature magnesian-ferrous hydromica, conditional formula $(\mathrm{K}, \mathrm{Na}, \mathrm{Ca})(\mathrm{Fe}, \mathrm{Al}, \mathrm{Mg}, \mathrm{Mn})_{2}(\mathrm{Si}, \mathrm{Al})_{4} \mathrm{O}_{10}(\mathrm{OH})_{2}$, having mica texture and diverse chemical composition [4]. The minerals in this group include random and /or rarely non-random dioctahedral lattice of subtype $1 \mathrm{M}$ and $1 \mathrm{Md}$, as well as uniform micro-concretion forms of aggregates which formed in marine sediments [5]. The criterion proving that glauconite is an indicator of ancient sedimentation conditions has been discussed in such publications as [6-13]. However, the issue concerning the diversified application of such a non-traditional mineral source has only been recently reflected in different publications.

Due to its specific properties - coloring oxides, active potassium cations, laminated structureglauconite is a valuable source applicable in agriculture. These minerals are used as compound mineral fertilizers, in livestock farming and fishery, production of emulsion and oil paints, water waste treatment etc [14-18]. Glauconite fraction in agriculture concentrates should be more than $40 \%$ (average $60 \ldots 70 \%$ ).

\footnotetext{
${ }^{\text {a }}$ Corresponding author: rudminma@tpu.ru
} 
Excluding the commercial value of glauconite rocks in Bakchar deposit, most probably, these rocks would be either extracted into disposal areas (during pit mining) or be concentration tailings. This fact itself significantly underestimates the true value of this deposit.

Consumers of glauconite products could be regional agrarian enterprises and petroleum refining sector, as well as chemical enterprises.

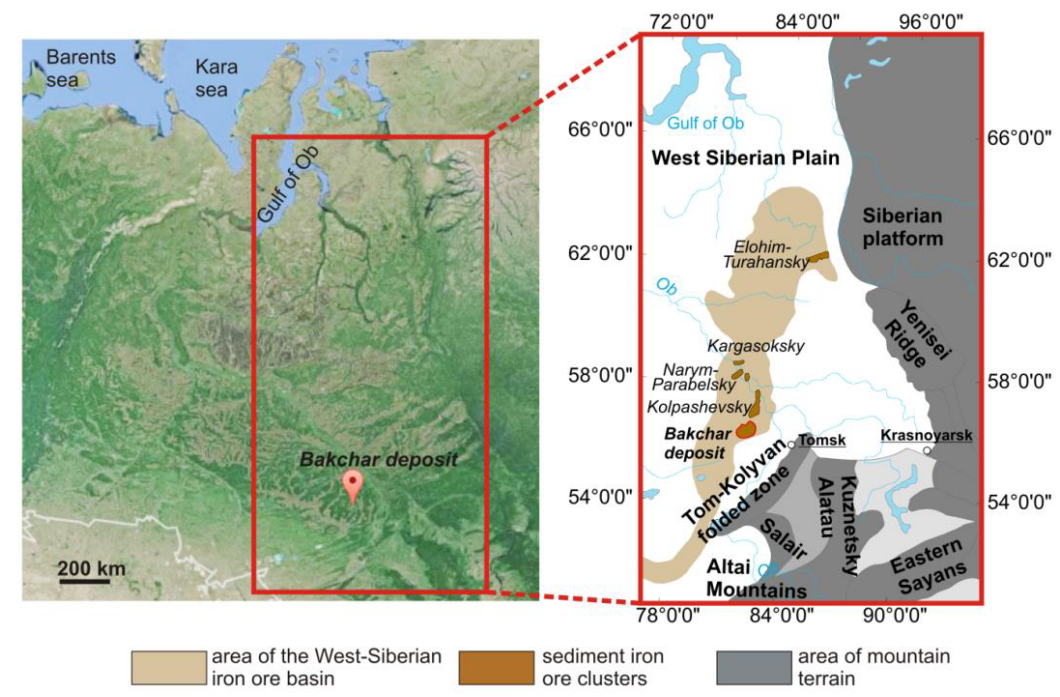

Figure 1. Overview map of Western-Siberian iron ore basin and Bakchar deposit
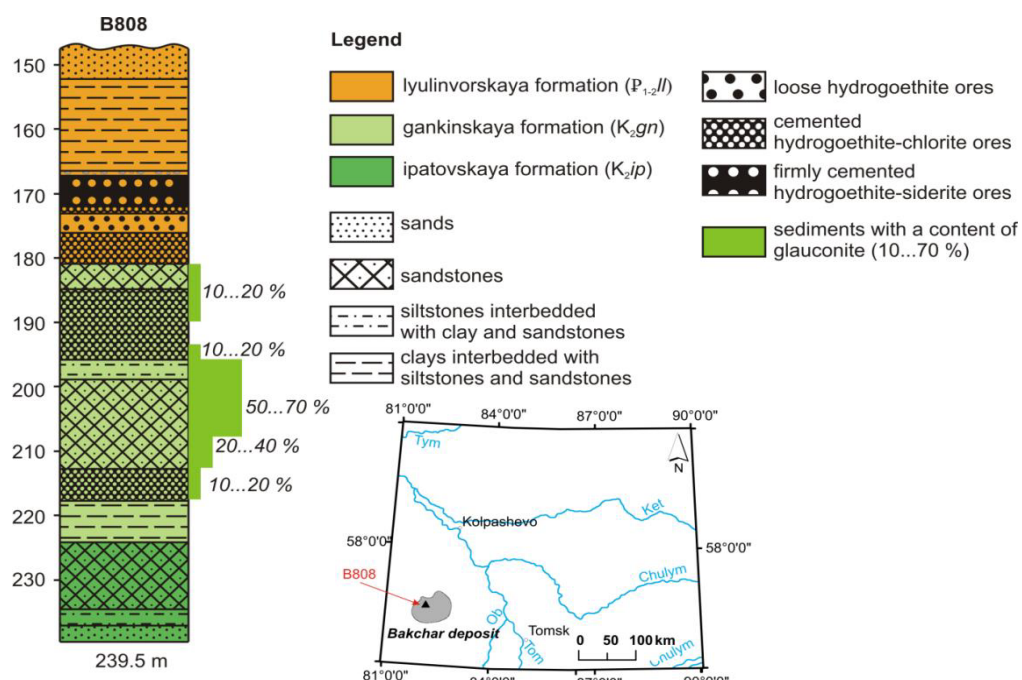

¿ sandstones

siltstones interbedded

$-=$ clays interbedded with

-7 siltstones and sandstones

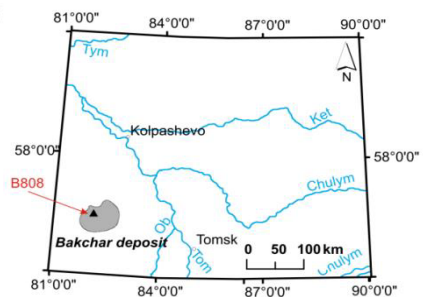

Figure 2. Detailed section of ore- hosting horizon in well (B808), Bakchar deposit

The authors consider that the application of glauconite as an associated component could enhance the pay-off period of the deposit. Investigating the producibility of glauconite rocks and their possible application in different economic sectors is a challenging advanced research task.

\section{Factual material and research methods}


The research material include core samples. All the glauconite rock samples were studied under petrographic microscope before developing the processing route. Glauconite liberation is based on "wet" screening to split the samples into granulometric classes: more than $1 \mathrm{~mm}, 1 \ldots 0.5 \mathrm{~mm}, 0.5 \ldots 0.2$ MM, $0.2 \ldots 0.1 \mathrm{~mm}$, less than $0.1 \mathrm{~mm}$. Granulometric classes $0.5 \ldots 0.2 \mathrm{~mm}$ and $0.2 \ldots 0.1 \mathrm{~mm}$ were split in electromagnetic ore separator (EVS 10/5) at current 3.5 ..1.8 A, on unmagnetic (more than $3.5 \mathrm{~A}$ ), submagnetic $(3.5 \ldots 1.8 \mathrm{~A}$ ) and magnetic (less than $1.8 \mathrm{~A}$ ) fractions. In each electromagnetic fraction the glauconite content is calculated by gravimetric method with monofraction selection under binocular microscope. The optimal processing route was developed on the basis of a small technological sample of $2 \mathrm{~kg}$.

Glauconite concentrate produced from the small technological sample was tested to evaluate its possible application in agriculture. Soil glauconite concentrate inoculation was performed in the following three steps. Soil dry glauconite inoculation included concentrations of 30,60 and 90 $\mathrm{kg} / \mathrm{hectar}$, and further distilled watering. Seed steeping in glauconite solution concentration of 0.0015 , $0.005 \%, 0.01 \%, 0.05 \%, 0.1 \%$ for 30 minutes before sowing and succeeding sowing and distilled watering. The last step - soil watering by $20 \mathrm{mliter}$ glauconite solution concentration of $0.03 \%, 0.06$ $\%, 0.09 \%$. All three- variant experiments were conducted in Petrie dish. Oat (Avéna satíva) germinating energy was determined on the $4^{\text {th }}$ experiment day, while germination $-7^{\text {th }}$ day. Plant height, herbage and dry mass die out on the $11^{\text {th }}$ day.

\section{Results and discussion}

Comparable to the Cauvery glauconite basin (India) [8]. Bakchar deposits include glauconite pellets, formed as a result of altered fecal pellets and glauconite infilling, developed within pores, cracks of fossil bioclasts. Glauconite pellets have isometric rounded (globular, nodular) morphological forms [19]; infilling - elongated globular, bunchy biomorphic aggregate compounds. The two major color variations were pistachio-green, green and greenish-yellow, greenish-brown. There are also grains of bluish-green, practically black, as well as yellow with light greenish hue. In this paper the terms glauconite "globule", "granule", "grain" and "ooid" are considered to be synonyms.

Crystal-chemical formula has an averaged form: $\mathrm{K}_{0.51}\left(\mathrm{Fe}_{1.83} \mathrm{Mg}_{0.24} \mathrm{Ca}_{0.05}\right)_{2.12}\left[\mathrm{Si}_{3.27} \mathrm{Al}_{0.69} \mathrm{O}_{10}\right](\mathrm{OH})_{2} \mathrm{nH}_{2} \mathrm{O}$. Content of basic oxides in glauconite ranges within the following limits: $\mathrm{K}_{2} \mathrm{O}-2.5 \ldots 7.7 \%, \mathrm{Fe}_{2} \mathrm{O}_{3 \text { (total) }}$ $-20.2 \ldots 69.4 \%, \mathrm{MgO}-1.7 \ldots 2.8 \%, \mathrm{CaO}-0.5 \ldots 0.9 \%, \mathrm{Al}_{2} \mathrm{O}_{3}-5.5 \ldots 11.5 \%, \mathrm{SiO}_{2}-32.5 \ldots 52.5 \%$, $\mathrm{H}_{2} \mathrm{O}-8.3 \ldots 12.3 \%$ (difference). Internal structure of glauconite globules is randomly distributed pallets and flakes with jagged contours.

It is well-known that [20] the producibility of raw glauconite is determined by the degree of glauconite-containing rock cementation and grained glauconite amount in the rock. In the Bakchar deposit cross-section glauconite rocks are confined to Gankin suite and extends to a depth of $180 \ldots 230$ meters (fig.2). Also glauconite rocks occur in the Upper Jurassic deposits of Western Siberia [21]. Sediments containing more than $10 \%$ glauconite and could be divided into three types, different in composition, texture and technological properties.

Glauconite ores (glauconitolite) (fig.3-a) includes $50 \ldots 70 \%$ granulated glauconite with insignificant impurities of terrigenous material. Rocks are bright green, rarely, dark green and tobacco green, usually nonstratified, sometimes, indistinctly stratified due to sunhorizontal pelitomorphic clots. The texture is aleuritic-(arenaceous) psammitic (rarely aleuritic), fine-grained, weakly-cemented. Cement is basal-porous, fine-grained, hydromica composition. Sometimes, one can observe micro-grained siderite impurities or thin veinlets, as well as phosphate and pyrite nodules in the cement. The fraction content of $0.2 \ldots 0.1 \mathrm{~mm}$ includes $37 \ldots 40 \% ; 0.5 \ldots 0.2-25 \ldots .34 \%$ and less than $0.1-25 \ldots 31 \%$. Glauconites are predominating green, tobacco, rarely black of less than $0.2 \mathrm{~mm}$. Globules have bladelike form. There is detritus in the rocks, whereas in some areas- coating sediment components. Glauconite ores possess the most favorable phase, morphological and technological criteria for industrial application. Applying these rocks as mineral fertilizers, nutritional environmental components (during reclamation etc.) and effective sorbents could be used without preliminary enrichment. Experimentally electromagnetic separation exhibited that magnetic fraction is "rich" 
glauconite concentrates with commercial component content of $90 \ldots 100 \%$, which, in its turn, could be used as a coloring pigment.

a
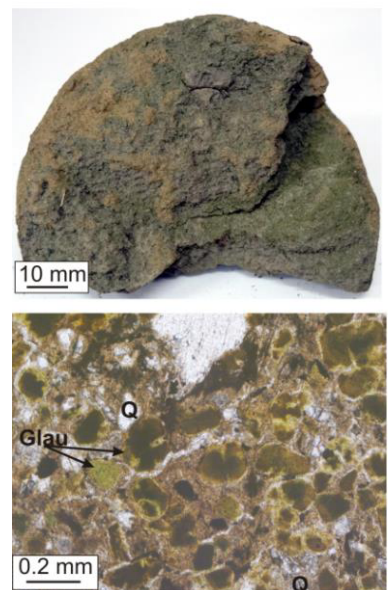

b
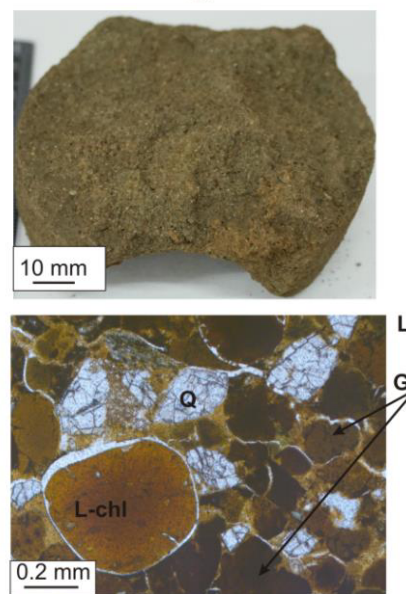
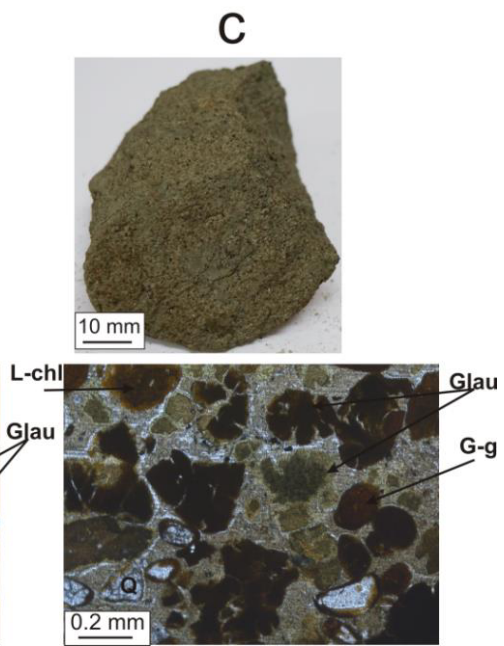

Figure 3. Photos of samples (top) and their images in transmission (bottom): a - glauconite ores (glauconites), b -glauconite sandstone, $\mathrm{c}$ - hydrogoethite-chlorite ore with glauconite, $\mathrm{Q}$ - quartz, Glau - glauconite, L-chl - leptochlorite ooid, G-g - hydrogoethite oolites

Table 1. Technological indicators of different glauconite rock categories

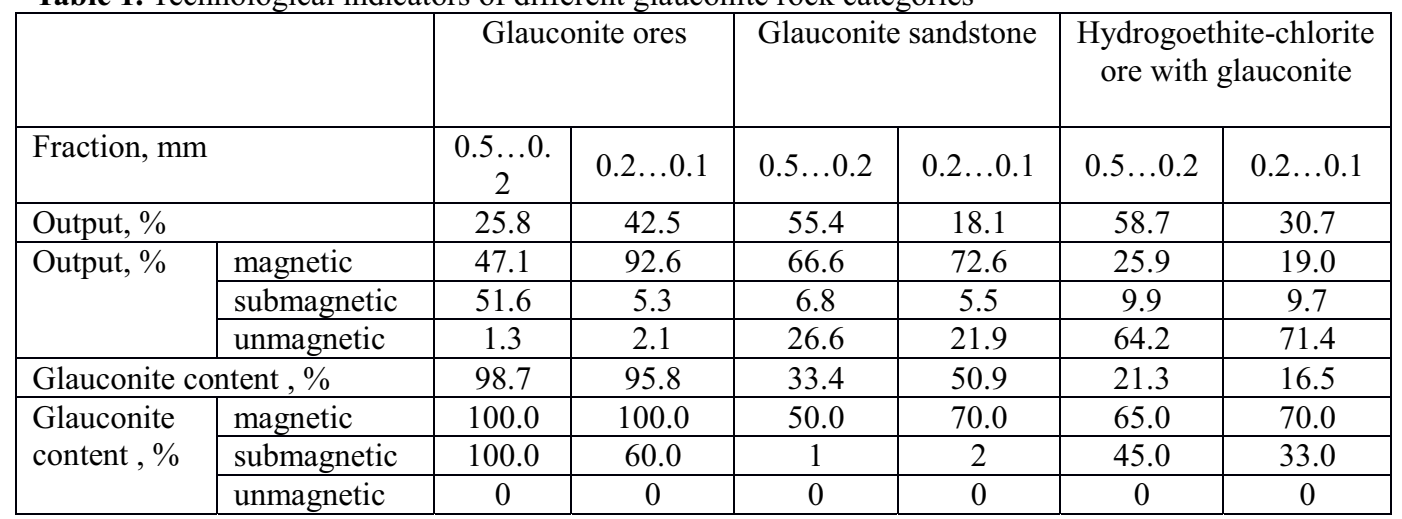

Glauconite sandstone (fig.3-b) includes $20 \ldots 40$ and up to $50 \%$ of grained glauconite, remaining is terrigenous matter, leptochlorite ooids and cement. The rocks are yellowish, greenish, dull tobacco, non-stratified. Texture- psammitic, medium- grained, weakly cemented. Cement - clay (hydromica), porous, micro-grained. The most significant output is granulometric fraction $0.5 \ldots 0.2 \mathrm{~mm}-45 \ldots 60 \%$. Tobacco and brownish glauconite has the following sizes $0.4 \ldots 0.1 \mathrm{~mm}$, whereas grain size is predominately less than $0.2 \mathrm{~mm}$. Through enrichment these rocks include the magnetic fraction of such concentrates as glauconite $-60 \ldots 70 \%$, hydrogoethite oolites and leptochlorite ooids $-10 \ldots 20$ $\%$, and clay particles up to $30 \%$. Technological properties indicate that this concentrate is applicable in agriculture, in livestock farming and fishery, as well as land reclamation.

Hydrogoethite-chlorite ores with glauconite (fig.3-c) include hydrogoethite oolites of $20 \ldots 25 \%$, leptochlorite ooid- $15 \ldots 20 \%$, glauconite $-10 \ldots 20 \%$, quartz $-10 \%$. The cement content in these rocks changes from clay to leptochlorite and in some cases, hydrogoethite. The cement is fine- 
crystalline and basal. Rocks are of tobacco color, non-stratified. Texture- psammitic, medium- grained to fine-grained, cemented sometimes, loose. Fraction content for $0.5 \ldots 0.2 \mathrm{~mm}$ is $53 \ldots 59 \%, 0.2 \ldots 0.1$ $-30 \ldots 38 \%$ and less than $0.1-9 \ldots 13 \%$. Iron oxide content in these ores changes from 26 to $36 \%$, which could be considered to be "poor" within this deposit. Glauconite grains are rounded, blade-like, micro-flaked of pistachio-green and tobacco color with numerous syneresis cracks. Different oxidized globules with brown crust of hydrooxide iron are predominate. Magnetic fraction in these rocks is glauconite of $50 \ldots 70 \%$, remaining being hydrogoethite oolites, leptochlorite ooids and aleuritic-clay clots of cementing matter. According to the technological criterion and composition this concentrate could be used in agriculture.

It should be noted that glauconite is always found in hydrogoethite-chlorite ores with a fraction of less than $10 \%$. Glauconite concentrates could be produced even if there is an insignificant content of this mineral under electromagnetic enrichment of this ore.

An integrated optimal scheme of producing glauconite concentrates was developed on the basis of the above-described glauconite rocks (fig. 4). Agrarian analysis involved the concentrate obtained from a small technological sample. Small technological sample including combined samples from three wells at the depth of $184 \ldots 186 \mathrm{~m}$ are "poor" hydrogoethite-chlorite iron ores with glauconite. Glauconite fraction in this sample is $18 \%$. The authors used this rock type to evaluate the possible associated extraction and application of glauconite in agriculture, being obtained from "poor" glauconitecontaining deposits. As a result of enriching small technological sample according to described scheme (fig.4) glauconite concentrate was produced. This concentrate (fig.5) includes granulometric glauconite of $71 \%$ and $29 \%$ from hydrogoethite oolites, leptochlorite ooids and aleuritic-clay clots of cementing matter.

The results of agrarian analysis proved the positive effect of glauconite concentrate on the growth of plants, especially oats (Avéna satíva). Soil dry glauconite inoculation where the concentrations are $3 \ldots 9 \mathrm{gr} / \mathrm{m}^{2}$ for $2.6 \ldots 8.6 \%$ increased germination energy up to $3.4 \ldots 10 \%$, at small and medium concentrations ( 3 and $6 \mathrm{gr} / \mathrm{m}^{2}$ ) increases herbage up to 8.2 and $11.7 \%$, respectively. If seed steeping in glauconite solution with concentrations of $0.001 \ldots 0.1 \%$ for $1.4 \ldots 7.4 \%$ increased plant growth and at $2 \ldots 4 \%$ - germination energy of oats. If watering the soil with glauconite solution of $0.03 \ldots 0.09 \%$ concentration the growth and development of plants insignificantly change.

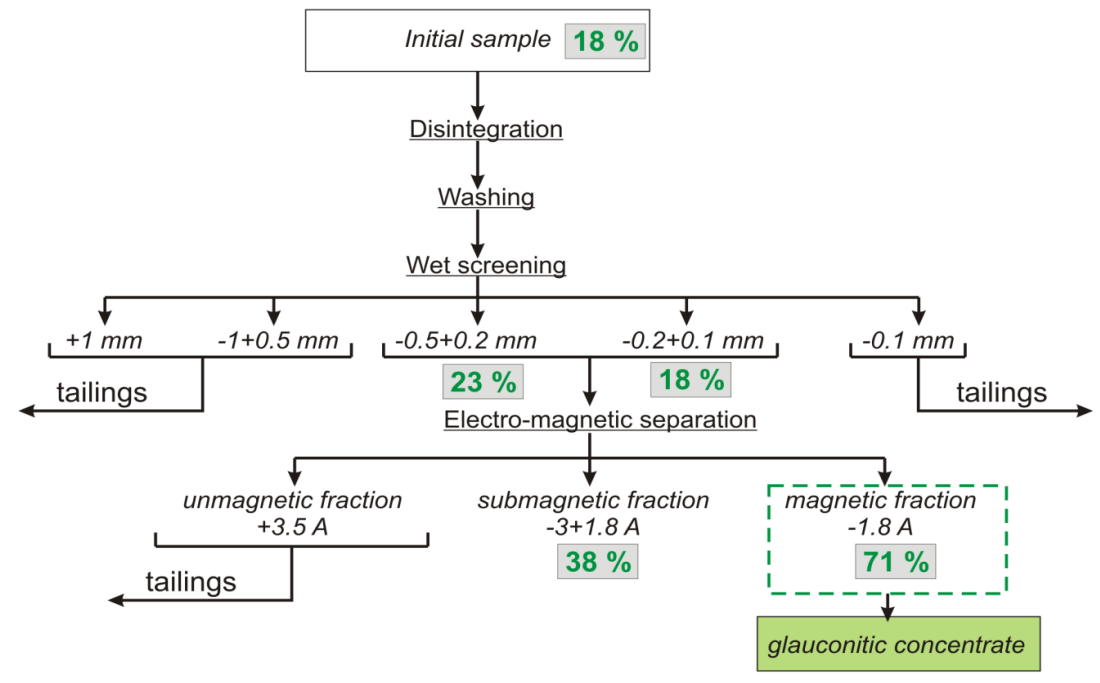

Figure 4. Technological scheme of producing glauconite concentrate from Bakchar deposit rocks. Green numbers refer to the glauconite content in corresponding products (fraction) from small technological sample of hydrogoethite-chlorite ore with glauconite. 


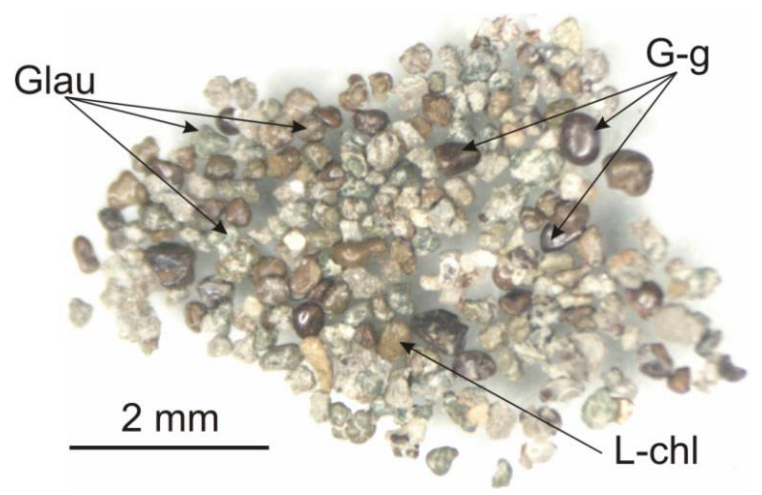

Figure 5. Photo of glauconite concentrate under binocular mircoscope, produced from small technological sample: Glau - glauconite, L-chl - leptochlorite ooids, G-g - hydrogoethite oolites

\section{Conclusion}

Several types of glauconite containing rocks were identified in the ore-hosting horizons of Bakchar deposit: glauconite ores (or glauconitolites), glauconite sandstones, hydrogoethite -chlorite iron ores with glauconite. Based on the research results the optimal processing route in producing glauconite concentrates from identified rocks was developed. Depending on the glauconite content in initial samples (rock type) concentrate enrichment was possible for further application. A product containing commercial component of $90 \ldots 100 \%$ was produced from glauconite ores. According to technological criteris this product is applicable in all economic segments where there is a demand for raw glauconite. Glauconite sandstones and iron ores with glauconite content of more than $10 \%$ under enrichment are especially applicable in agriculture.

Agrarian analysis showed that adding glauconite concentrate produced from enriched "poor" iron ores could increase oat germination. Soil glauconite concentrate $\left(3 \ldots 9 \mathrm{gr} / \mathrm{m}^{2}\right)$ inoculation results in increasing germinating energy, germination and herbage.

Obtained results prove the fact that it is more profitable and efficient to use Bakchar glauconite in agriculture. As a secondary by-product raw glauconite could further the development of this deposit.

\section{Acknowledgements}

This study was supported by the Russian Foundation for Basic Research and Tomsk Region Administration (project no. 16-45-700090). The authors express their thanks to employees of the Siberian Research Institute of Agriculture and Peat Zmeeva O.N., Proskurina L.D. and Petrova L.V. for the performance of agricultural research.

\section{References}

1. M.A. Rudmin, A.K. Mazurov, A.S. Ruban. IOP Conf. Ser. Earth Environ. Sci. 24. 012028 (2015)

2. M.A. Rudmin, I.V. Reva, A.P. Gunko, A.K. Mazurov, R.N. Abramova. IOP Conf. Ser. Earth Environ. Sci. 27. 012026 (2015)

3. West Siberian iron ore basin (1964)

4. I. Nikolaeva. Minerals of Glauconite Group in Sedimentary Formations 319 (1977) (in Russian)

5. V.A. Drits, A.G. Kossovskaya. Lithology and mineral resources. 5. 563-580 (1986) 
6. S. Banerjee, S.L. Chattoraj, P.K. Saraswati, S. Dasgupta, U. Sarkar. Marine and Petroleum Geology. 30. 144-160 (2012)

7. S. Banerjee, S.L. Chattoraj, P.K. Saraswati, S. Dasgupta, U. Sarkar, A. Bumby. India Geological Journal. 47. 357-371 (2012)

8. S. Banerjee, U. Bansal, K. Pande, S.S. Meena. Sedimentary Geology. 331. 12-29 (2016)

9. S. Banerjee, U. Bansal, A.V.Thorat. Journal of Palaeogeography. 5 (1). $43-71$ (2016)

10. A.G. Kossovskaya, V.A. Drits. Sedimentology. 15. 83-101 (1970)

11. A. Meunier, A. El Albani. Terra Nova. 19. 95-104 (2007)

12. G.S. Odin, A. Matter. Sedimentology. 28. 611-41 (1981)

13. R. Wigley, J.S. Compton. Research II. 54. 1375-1395 (2007)

14. E. Dutova, I. Vologdina, D. Pokrovsky, N. Nalivaiko, K. Kuzevanov, V. Pokrovsky. IOP Conference Series: Earth and Environmental Science. 33 (1). 012017 (2016)

15. V. Lyashko, V. Zabilov, I. Dobrovolski. AIC Russia. 72(2). 141-148 (2015)

16. S.S. Mandzhieva, T.M. Minkina, S.N. Sushkova, G.V. Motuzova, T.V. Bauer, V.A. Chapligin American Journal of Agricultural and Biological Science. 9 (1). 19-24 (2013)

17. N. Rahimzadeh, F. Khormali, M. Olamaee, A. Amini, E. Dordipour. Biology and Fertility of Soils. 51 (8). 973-981 (2015)

18. A.K. Yapparov, L.M. Bikkinina, I.A. Yapparov, S.A. Aliev, A.M. Ezhkova, V.O. Ezhkov, R.R Gazizov. Eurasian Soil Science. 48 (10). 1149-1158 (2015)

19. M.A. Rudmin, A.K. Mazurov, L.M. Bolsunovskaya. IOP Conf. Ser. Earth Environ. Sci. 21. 012003 (2014)

20. E. Levchenko, N. Ptyk-kara, M. LEvchenko. International Geological Congress (2008)

21. L. Krasnoschekova, D Cherdansteva, R. Abramova. IOP Conf. Ser. Earth Environ. Sci. 24. $012018(2015)$ 